\title{
Genetic Correlation of Inhibitory Gating of Hippocampal Auditory Evoked Response and $\alpha$-Bungarotoxin-Binding Nicotinic Cholinergic Receptors in Inbred Mouse Strains
}

\author{
Karen E. Stevens, Ph.D., Robert Freedman, M.D., Allan C. Collins, Ph.D., Michael Hall, Ph.D., \\ Sherry Leonard, Ph.D., Michael J. Marks, Ph.D., and Gregory M. Rose, Ph.D.
}

One function of the hippocampus is to ascertain the novelty of incoming sensations and encode significant new information into memory. The regulation of response to repeated stimuli may prevent overloading of this function by redundant sensory input. Recent pharmacological studies implicate the role of $\alpha$-bungarotoxin-sensitive nicotinic cholinergic receptors in the inhibition of hippocampal response to repeated auditory stimuli. The number of hippocampal $\alpha$-bungarotoxin-sensitive receptors has a major genetic determinant, as demonstrated by a significant variance between different inbred mouse strains. The purpose of the present study was to determine whether there was a related genetic correlation for the gating of auditory response. Nine inbred mouse strains, representing a continuum of hippocampal $\alpha$-bungarotoxin binding, were tested for the electrophysiological response to repeated auditory stimulation, followed by whole hippocampus membrane $\alpha$-bungarotoxin binding studies. Several parameters of the auditory evoked response showed significant genetic variance over the nine strains, and a significant correlation was found between hippocampal $\alpha$-bungarotoxin binding and both the amplitude of the initial evoked response and its inhibition to repeated auditory stimuli. There was no correlation of the auditory evoked response with high-affinity nicotine binding. These data further support the hypothesis that $\alpha$-bungarotoxinsensitive nicotinic receptors are involved in the regulation of hippocampal response to repeated auditory stimuli and suggest that this function is genetically controlled.

[Neuropsychopharmacology 15:152-162, 1996]
KEY WORDS: Auditory evoked potentials; Habituation; Hippocampus; Cholinergic receptors; Nicotinic receptors; Inbred mice

From the Departments of Psychiatry (KES, RF, MH) and Pharmacology (SL; GMR), University of Colorado Health Sciences Center Denver, CO; the Medical Research Service (KES, RF, SL, GMR), Veterans Administration Medical Center, Denver, $\mathrm{CO}$; and the Institute for Behavioral Genetics (ACC, MJM), Boulder, CO.

Address correspondence to: Robert Freedman, M.D., Department of Psychiatry, C268-71, University of Colorado Health Sciences Center, 4200 E. Ninth Avenue, Denver, Colorado 80262.

Received June 9, 1995; revised September 13, 1995; accepted September 14,1995
One of the functions of the hippocampus is to compare incoming information from the surrounding environment with existing memories and to encode significant new information into new memories (Swanson 1983). Relative to the amount of sensory information in the environment, however, the capacity of the brain to process incoming information appears limited (Broadbent 1958). Thus, the hippocampus has mechanisms that regulate its response to sensory stimuli in order to process only novel or critical information. This function has been termed "inhibitory gating" because inhibitory neurotransmitter mechanisms are used to gate or con- 
trol the effect of sensory input on neuronal activity (Freedman et al. 1994). For example, hippocampal CA3 neurons rapidly habituate their response to repeated auditory stimuli (Vinogradova 1975). This habituation may be one mechanism to prevent redundant sensory information from utilizing the limited neuronal resources available for memory encoding. The entorhinal cortex, one of the principal relay centers for sensory information into the hippocampus, does not show such habituation of response (Stafekhina and Vinogradova 1975), which suggests that the dentate gyrus and CA3 pyramidal neurons may be critical for the regulation of hippocampal information flow. Lesions of the fimbriafornix, which carries cholinergic afferents to the hippocampus from the medial septal nucleus (Amaral and Kurz 1985), block the habituation of hippocampal response (Foster et al. 1988; Senba and Iwahara 1974; Vinogradova 1975). Unlike entorhinal cortex neurons, cholinergic medial septal neurons exhibit a diminished response to repeated auditory stimuli (Miller and Freedman 1993). Thus, a cholinergic mechanism may be involved in the regulation of hippocampal response to auditory stimulation.

Pharmacological studies of the effects of various cholinergic antagonists on the hippocampal evoked response to repeated sensory stimulation provide further evidence for this hypothesis. The P20-N40 auditory evoked potential, recorded from the rat $\mathrm{CA} 3$ region, shows diminished response to the second of two auditory stimuli presented $0.5 \mathrm{sec}$ apart (Bickford-Wimer et al. 1990). Intraventricular administration of scopolamine, a muscarinic antagonist, had no effect on this habituation of response to repeated stimuli. Mecamylamine and $\kappa$-bungarotoxin, which block high-affinity nicotine receptors by various mechanisms, were also without effect. However, $\alpha$-bungarotoxin and d-tubocurarine both significantly decreased the inhibition of response to the second of the stimuli (Luntz-Leybman et al. 1992). Similar antagonism was demonstrated with methyllycaconitine, an antagonist that competes with $\alpha$-bungarotoxin at neuronal nicotinic receptors (Rollins et al. 1994). These pharmacological studies thus suggest that a nicotinic receptor sensitive to $\alpha$-bungarotoxin and related antagonists is involved in this inhibition of response to repeated stimuli. $\alpha$-Bungarotoxin binds to postsynaptic sites on pyramidal cells in the hippocampus (Hunt and Schmidt 1978), but the binding is particularly concentrated over a subset of hippocampus interneurons (Freedman et al. 1993). Recently, the $\alpha-7$ nicotinic receptor unit, which forms a receptor complex that binds $\alpha$-bungarotoxin, has been cloned (Schoepfer et al. 1990). Its distribution in the rat central nervous system includes expression in the hippocampus (Johnson et al. 1991). Rapid desensitization of its response to both nicotine and acetylcholine, apparent in its initial characterization in frog oocytes (Couturier et al. 1990), may explain why many previous electrophysiological studies have failed to demonstrate a functional role for $\alpha$-bungarotoxin-sensitive receptors (Clarke 1992).

As with many neurotransmitter receptors, the expression of $\alpha$-bungarotoxin-sensitive receptors is regulated genetically. Different inbred mouse strains vary significantly in the level of $\alpha$-bungarotoxin binding in the hippocampus (Miner et al. 1986; Marks et al. 1989; Miner and Collins 1989). The amount of binding in these strains is correlated with sensitivity to nicotineinduced seizures, but not to other nicotine-induced behavioral changes such as rearing or hypothermia. These other behaviors correlate with high-affinity nicotine binding, which is not correlated with $\alpha$-bungarotoxin binding.

This genetic variance in $\alpha$-bungarotoxin-sensitive nicotinic receptors makes possible investigation of several issues about the gating of auditory evoked response in the hippocampus. First, significant variance in parameters of the auditory evoked response across inbred mouse strains would suggest that these parameters are also under genetic control. Second, a correlation analysis between the auditory evoked response and $\alpha$-bungarotoxin binding could then be used to estimate the extent to which the two traits had common genetic influences. Such genetic correlational analyses have been used in other contexts to relate genetically determined differences in behavior to genetically determined differences in a particular neuronal mechanism (Wehner et al. 1990).

\section{MATERIALS AND METHODS}

\section{Electrophysiology}

Male mice (25-32 g) of the ST/b, C3H, C57/B1, BALB, $\mathrm{BUB} / \mathrm{Ibg}$, and DBA/2lbg strains were obtained from the Institute for Behavioral Genetics (Boulder, $\mathrm{CO}$ ). Mice of the BUB/J, AKR, and DBA/1J strain were purchased from Jackson Laboratories (Bar Harbor, ME). Prior to acute recording sessions, mice were housed four per cage and permitted free access to food (Purina Rodent (how) and water. Lighting was cycled every 12 hours (lights on at 6:00 A.M.).

The mice were anesthetized with chloral hydrate (400 $\mathrm{mg} / \mathrm{kg}$, Ip) with pyrazole supplementation (400 $\mathrm{mg} / \mathrm{kg}$, Ip) to retard metabolism of the anesthetic. Additional doses of chloral hydrate and pyrazole were administered every 30 to 60 minutes as needed to maintain a surgical plane of anesthesia as assessed by toepinch and blink response. The mouse was placed in a Neuroprobe mouse adaptor (Neuroprobe, Cabin John, MD) for the Kopf stereotaxic instrument (David Kopf Instruments, Tajunga, CA), and the skin over the skull was incised and retracted. A small burr hole was opened in the skull over the dorsal hippocampus [1.8 
$\mathrm{mm}$ posterior to bregma, $2.7 \mathrm{~mm}$ lateral to midline (Slotnick and Leonard 1975)]. A tungsten microelectrode (average impedance $0.3-0.8 \mathrm{M} \Omega$ ) was lowered to the CA3 pyramidal cell layer of the hippocampus (approximately $1.8 \mathrm{~mm}$ below brain surface) to record auditory evoked potentials. Neuronal activity was monitored continuously during lowering of the electrode into the hippocampus. The presence of multiple-unit discharges, often containing complex spikes, indicated placement of the recording electrode in the CA3 pyramidal cell layer.

The auditory stimulus was a 10 -msec epoch of a $3-\mathrm{kHz}$ sine wave, $75-\mathrm{dB}$ sound pressure level, which was delivered binaurally through hollow stereotaxic ear bars placed at the externalization of the aural canals. Identical stimuli were delivered in pairs, $0.5 \mathrm{sec}$ apart, at $10-\mathrm{sec}$ intervals in a conditioning-test paradigm. In this paradigm, inhibitory mechanisms are assessed by comparison of the amplitude of the two evoked responses. The diminished amplitude of the second response, as compared to the first, "tests" the strength of the inhibitory mechanisms activated, or "conditioned," during the first response. The ratio of the amplitude of the test response to the conditioning response amplitude indicates the amount of inhibition, with lower ratios indicative of stronger inhibition (Andersen et al. 1964).

Auditory evoked activity was recorded in the hippocampus via a high-input impedance amplifier, with bandpass filtering of 1 to $500 \mathrm{~Hz}$ (A-M Systems, Newark, NJ), which amplified the signal 1,000 times. The signal was then digitized at $1,000 \mathrm{~Hz}$. A computer automatically recorded and averaged the potentials elicited by 16 paired auditory stimuli. The amplitude of the most negative-going wave recorded in response to the first (conditioning) stimulus within a window 20 to 45 msec after stimulus onset (N40) was measured from the peak of the preceding positivity, which occurred 10 to $20 \mathrm{msec}$ after the stimulus onset (P20). The amplitude of the P20-N40 response to the second (test) stimulus was measured in the same manner. For this auditory evoked response, such peak-to-peak measurements have been shown to be more reliable than measurement of either component alone (Cook et al. 1968). The ratio of the test amplitude to conditioning amplitude was determined for each averaged evoked potential. The mean of values from three averaged evoked potentials was determined for each mouse for subsequent statistical analysis.

\section{$\alpha$-Bungarotoxin Binding}

At the end of the recording session, the mice were given an overdose of anesthetic and then decapitated. The brain was then quickly removed, frozen in isopentane on dry ice, and subsequently stored at $-70^{\circ} \mathrm{C}$ until sectioned. Regional dissections were made of brains of three mice from each strain. Membrane binding studies were performed on the hippocampus to assess levels of $\alpha$-bungarotoxin binding. In addition, tissue from four selected strains (ST/b, C3H, C57/B1, and DBA/2lbg) of mice ( $n=4$ per strain) were sectioned on a cryostat for autoradiographic assessment of relative levels of hippocampal $\alpha$-bungarotoxin binding and in situ hybridization for the mRNA for the $\alpha-7$ subunit of the nicotinic receptor. The tissue was cut into $12-\mu \mathrm{m}$ sections and thaw-mounted onto poly-l-lysine-coated slides. A section from each strain was included on each slide.

The methods for tissue preparation and binding parameters for determination of membrane binding levels of $\alpha$-bungarotoxin have been published elsewhere (Marks et al. 1989). Briefly, the tissue was homogenized in 10 volumes of ice-cold Krebs-Ringer's HEPES buffer (Boehringer-Mannheim, Indianapolis, IN) using a Teflon pestle. Following several washes and centrifugations at $18,000 \times g$ for 20 minutes, the pellet was resuspended in 10 volumes of Krebs-Ringer's HEPES buffer, and diisopropylflurophosphate (DFP, Sigma Chemical Co., St. Louis, MO) was added to a final concentration of 100 $\mu \mathrm{M}$. Following a 10 -minute incubation at $37^{\circ} \mathrm{C}$, the homogenate was centrifuged at $18,000 \times g$ for 20 minutes, and the pellet was resuspended in Krebs-Ringer's HEPES plus $100 \mu \mathrm{M}$ DFP.

Binding of $\left[{ }^{125} \mathrm{I}\right] \alpha$-bungarotoxin $(2 \mathrm{nM}, 244 \mathrm{Ci} /$ mMole, Amersham Corp., Arlington Heights, IL) took place in Krebs-Ringer's HEPES buffer containing 0.01\% bovine serum albumin (BSA, Sigma Chemical Co., St. Louis, MO) using polypropylene test tubes and an incubation volume of $500 \mu$ l. The samples contained 50 to $250 \mu \mathrm{g}$ protein. Incubations were conducted for 4 hours at $37^{\circ} \mathrm{C}$ and terminated by dilution of the sample with ice-cold buffer and filtration on to Boehringer-Mannheim glass-fiber filters (Indianapolis, IN) that had been soaked in buffer containing $0.5 \%$ polyethylenimine (Sigma Chemical Co., St. Louis, MO). The filters were washed five times with 3-ml aliquots of buffer containing $0.5 \%$ polyethylenimine. Nonspecific binding was defined by addition of $1 \mathrm{mM}$ 1-nicotine (Sigma Chemical Co., St. Louis, MO) to half the samples.

After filtration, the washed filters were placed in 7-ml scintillation vials containing $2.5 \mathrm{ml}$ of Safety Solve scintillation fluid (Research Products International, Mt. Prospect, IL). The samples were capped, mechanically shaken, and counted on a Beckman 1800 Liquid Scintillation Spectrometer. Protein was assayed by the method of Lowry et al. (1951) using BSA as the standard. Specific $\alpha$-bungarotoxin binding was calculated as fmol/ mg protein.

\section{Autoradiography}

For autoradiographic visualization of hippocampal $\alpha$-bungarotoxin binding, slides with tissue sections were preincubated in $50 \mathrm{mM}$ Tris- $\mathrm{HCl}$ buffer, $\mathrm{pH} 7.4$, contain- 
ing $120 \mathrm{mM} \mathrm{NaCl}$ and $2 \mathrm{mg} / \mathrm{ml}$ BSA for 0.5 hour at room temperature. Half the slides were then incubated in buffer containing $2 \mathrm{nM}\left[{ }^{125} \mathrm{I}\right]-\alpha$-bungarotoxin $(2000 \mathrm{Ci} /$ nmole); the other half were incubated in buffer containing the labeled $\alpha$-bungarotoxin plus $1 \mathrm{mM}$ unlabeled 1-nicotine to define nonspecific binding. Following incubation for 3 hours at $37^{\circ} \mathrm{C}$, the slides were washed three times for 10 minutes each in room-temperature phosphate-buffered saline (PBS) (pH 7.4). The first two washes contained BSA; the third did not. After drying, the slides were dipped in Kodak NTB2 photographic emulsion. After 7 days, the emulsion was developed using Dektol (1:1) and the tissue was subsequently counterstained with cresyl violet.

The slides were analyzed on a Joyce-Loebl Magiscan MD2 computer-based imaging system. Silver grain densities were measured in hippocampal areas CA1, CA3, and the dentate granule cell layer. Values obtained from slides incubated with 1-nicotine, representing nonspecific binding, were subtracted from the values obtained with labeled $\alpha$-bungarotoxin alone, representing total binding, to give a value for specific binding. Binding densities were expressed as a fraction of the value obtained on the same slide from the strain with highest binding, the ST/b strain.

\section{In Situ Hybridization}

Assessment of levels of mRNA for the $\alpha-7$ subunit of the nicotinic receptor was performed using a cRNA probe prepared from cDNA for the rat $\alpha-7$ subunit (obtained from Dr. James Boulter, The Salk Institute, San Diego, CA). A restriction fragment of 500 basepairs, coding for the amino terminus of the mature peptide, was subcloned into a BlueScript vector (Stratagene, La Jolla, CA) containing T7 and T3 polymerase promoter sequence. The plasmid was linearized with Sac1 or EcoR1 restriction enzymes (Boehringer Mannheim, Indianapolis, IN) that cut to the $5^{\prime}$ and $3^{\prime}$ end of the cDNA insert, respectively. The cDNA was then transcribed in vitro using a kit from Ambion (Austin, TX). Transcription took place with T7 or T3 polymerases in the presence of $\left[{ }^{35} \mathrm{~S}\right]$-uridine-triphosphate (Amersham, Arlington Heights, IL) and unlabeled adenosine triphosphate, cytosine triphosphate, and guanosine triphosphate (Ambion, Austin, TX) to generate sense and antisense cRNA probes, respectively (Logel et al. 1992). Unincorporated nucleotides were removed by passage through a G50 Spin Column (Boehringer Mannheim, Indianapolis, IN). An aliquot of each probe was counted on a Beckman LS7800 scintillation counter; the specific activity of the probes was determined to be $7.1 \times 10^{5} \mathrm{cpm} /$ $\mathrm{ml}$ for the antisense probe and $3.9 \times 10^{6} \mathrm{cpm} / \mathrm{ml}$ for the sense probe. Probes were stored overnight at $-20^{\circ} \mathrm{C}$ and used the next day.
In situ hybridization was performed according to previously published methods (Marks et al. 1992; Simmons et al. 1989). Slides containing the tissue sections were incubated at room temperature in PBS, $\mathrm{pH} 7.4$, containing $4 \%$ paraformaldehyde for 15 minutes, after which they were washed three times for 5 minutes each in PBS alone and then air-dried. The slides were then incubated in $0.1 \mathrm{M}$ triethanolamine buffer (TEA, Sigma Chemical Co., St. Louis, MO), pH 8.0, for 3 minutes and then in TEA containing $15 \mathrm{mM}$ acetic anhydride for 10 minutes. They were then rinsed twice in $2 \times$ SSC $(1 \times$ $\mathrm{SSC}=150 \mathrm{mM} \mathrm{NaCl}$ plus $15 \mathrm{mM}$ trisodium citrate, $\mathrm{pH}$ 7.4). The tissue was dehydrated by passing the slides through successive 3-minute ethanol baths $(50 \%, 70 \%$, $95 \%$, and $100 \%$ ), after which the slides were air-dried. Hybridization took place in buffer containing $50 \%$ formamide, $10 \%$ dextran sulfate, $300 \mathrm{mM} \mathrm{NaCl}, 10 \mathrm{mM}$ Tris- $\mathrm{HCl},(\mathrm{pH} 8.0), 1 \mathrm{mM}$ EDTA ( $\mathrm{pH} 8.0$ ), Denhardts $(0.02 \%$ each BSA, Ficoll and polyvinylpyrrolidone, Sigma Chemical Co., St. Louis, MO), $500 \mu \mathrm{g} / \mathrm{ml}$ yeast extract tRNA, $10 \mathrm{mM}$ dithiothreitol (DTT, Sigma Chemical Co., St. Louis, MO) and $5 \times 10^{6} \mathrm{cpm} / \mathrm{ml}$ of the sense or antisense probe. After hybridization at $58^{\circ} \mathrm{C}$ for 18 hours, the incubation buffer was cooled to room temperature and the slides washed for 15 minutes in $4 \times$ SSC with agitation. The slides were subsequently transferred to ribonuclease-containing buffer $(20 \mu \mathrm{g} / \mathrm{ml}$ RNAse A, $500 \mathrm{mM} \mathrm{NaCl}, 10 \mathrm{mM}$ Tris- $\mathrm{HCl}, \mathrm{pH} 8.0$, and $1 \mathrm{mM}$ EDTA) for 30 minutes at $37^{\circ} \mathrm{C}$. The tissue was then washed and desalted in 5-minute baths of decreasing concentrations of SSC containing $1 \mathrm{mM}$ DTT to prevent oxidation of the $\left[{ }^{35} \mathrm{~S}\right]$-containing probes. A final 30 minute high-stringency wash containing $0.1 \times$ SSC and $1 \mathrm{mM}$ DTT at $60^{\circ} \mathrm{C}$ was followed by a 10 -minute cooling period in $0.1 \times$ SSC plus $1 \mathrm{mM}$ DTT at room temperature. The tissue was then dehydrated by successive 3-minute washes in increasing concentrations of ethanol. The slides were air-dried and apposed to Hyperfilm- ${ }^{3} \mathrm{H}$ (Amersham, Arlington Heights, TX) for 10 days. Following development of the film, the images were analyzed on the Joyce-Loebl Magiscan MD2 computer-based imaging system, as was described for the autoradiographic $\alpha$-bungarotoxin binding studies. Grain densities obtained for the sense probe images were subtracted from the antisense images to define selective hybridization for each of the hippocampal areas. Levels of $\alpha-7$ subunit mRNA were expressed relative to the ST $/ \mathrm{b}$ strain.

\section{Data Analysis}

Interstrain differences in a single variable were assessed by analysis of variance (ANOVA). Pearson's correlation was used to express the relationship between variables across strains. 


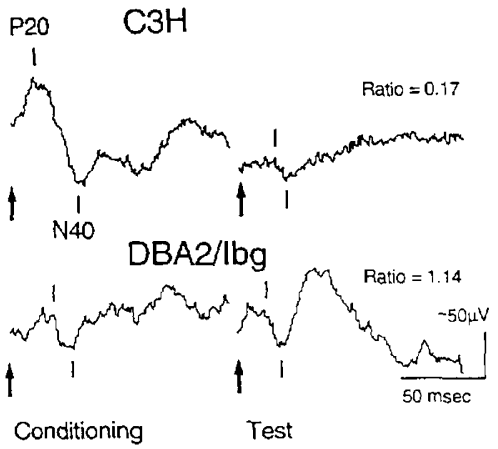

Figure 1. Auditory evoked potentials from a $\mathrm{C} 3 \mathrm{H}$ and a DBA/2lbg mouse. The stimuli are indicated by arrows. The $\mathrm{N} 40$, indicated by the tic below each trace, was measured relative to the preceding P20 positivity, indicated by the tic above each trace.

\section{RESULTS}

\section{Auditory Evoked Responses}

Auditory evoked responses were recorded from the hippocampus in all nine mouse strains. Latencies of the potentials did not differ significantly across the strains and were within the range for N40 latency $(38-42 \mathrm{msec})$ found in previous studies in anesthetized rats (Bickford-Wimer et al. 1990). However, the amplitude of responses to both conditioning and test stimuli varied significantly across the strains. The sample recording from a $\mathrm{C} 3 \mathrm{H}$ mouse shows a lower response to the test stimulus than to the conditioning stimulus, which is also similar to that previously reported in rats, whereas the sample recording from the DBA/2lbg mouse shows a smaller response to the conditioning stimulus and no decrement in the test response (Figure 1). The DBA/1J strain, which has been genetically separate since 1930 from all DBA/ 2 strains, including DBA/2lbg, had a similar evoked response, despite other behavioral differences (Yanovsky et al. 1995). Evoked response parameters of the other strains varied continuously across a range of values (Table 1). Across the nine strains, there were significant differences in the amplitude of the conditioning response $[F(8,51)=4.78, p<.0005]$ in the amplitude of the test response $[F(8,51)=2.15, p<.05]$ and in the ratio of the test response to the conditioning response $[F(8,51)=12.57, p<.0001]$. There were no significant correlations between conditioning amplitude and either test amplitude or the ratio of test to conditioning amplitude.

\section{[125I]- $\alpha$-Bungarotoxin Binding}

The binding of $\left[{ }^{125} \mathrm{I}\right]-\alpha$-bungarotoxin in the hippocampus also showed significant differences across the nine strains. A previous study using Scatchard analysis showed no difference in $K_{D}$ values between the strains and determined that $2 \mathrm{nM}$, the concentration used in the present study, would saturate the binding site (Marks et al. 1989). At saturating concentration, the previous study also reported significant differences in binding in the hippocampus and other brain regions. Three mice in each strain were selected from those used for electrophysiological recording to repeat the analysis. Analysis of variance of the present data showed results consistent with those previously obtained $[F(8,18)=$ $3.29, p<.05$; Table 2]. The correlation between the values observed in the two studies was significant $(r=$ $0.88, p<.005)$.

\section{Comparison between Auditory Evoked Response and Binding of $\left[{ }^{125} I\right]-\alpha$-Bungarotoxin and $\left[{ }^{3} \mathrm{H}\right]$-Nicotine}

Across the nine strains, there was a significant correlation between $\left[{ }^{125} \mathrm{I}\right]-\alpha$-bungarotoxin binding and both the conditioning amplitude $(r=0.75, p<.01)$ and the ratio of the test amplitude to the conditioning amplitude $(r=-0.72, p<.05$; Figure 2). There was no significant correlation between test amplitude and $\left.{ }^{125} \mathrm{I}\right]-\alpha$-bungarotoxin binding. None of the evoked potential parameters correlated with $\left[{ }^{3} \mathrm{H}\right]$-nicotine binding levels that

Table 1. Amplitudes and TC Ratios for Auditory Evoked Potentials Recorded in Nine Strains of Inbred Mice

\begin{tabular}{lccc}
\hline Strain & $\begin{array}{c}\text { Condition Amplitude } \\
(\mu \text { Volts) }\end{array}$ & $\begin{array}{c}\text { Test Amplitude } \\
(\mu \text { Volts) }\end{array}$ & $\begin{array}{c}\text { Ratio of Test } \\
\text { to Condition Amplitude }\end{array}$ \\
\hline AKR $(n=6)$ & $35.6 \pm 7.3$ & $14.2 \pm 3.2$ & $0.45 \pm 0.09$ \\
BALB $(n=5)$ & $93.1 \pm 21.8$ & $81.7 \pm 21.3$ & $0.90 \pm 0.07$ \\
BUB $/ \operatorname{lbg}(n=6)$ & $175.3 \pm 50.8$ & $76.1 \pm 35.0$ & $0.36 \pm 0.11$ \\
BUB $/ \mathrm{J}(n=5)$ & $137.6 \pm 64.5$ & $66.0 \pm 30.2$ & $0.48 \pm 0.05$ \\
C3H $(n=6)$ & $116.2 \pm 14.0$ & $8.0 \pm 3.6$ & $0.08 \pm 0.03$ \\
C57/Bl $(n=8)$ & $114.7 \pm 15.4$ & $27.0 \pm 5.4$ & $0.27 \pm 0.05$ \\
DBA $/ 1 \mathrm{~J}(n=5)$ & $42.9 \pm 13.3$ & $42.2 \pm 15.9$ & $0.96 \pm 0.12$ \\
DBA $/ 2 \operatorname{lbg}(n=8)$ & $52.4 \pm 14.5$ & $39.9 \pm 8.4$ & $0.91 \pm 0.15$ \\
ST $/ \mathrm{b}(n=11)$ & $285.5 \pm 57.5$ & $96.9 \pm 23.4$ & $0.31 \pm 0.04$ \\
\hline
\end{tabular}


Table 2. $\left[{ }^{125} \mathrm{I}\right]-\alpha-$ Bungarotoxin Binding in Inbred Mouse Strains

\begin{tabular}{lc}
\hline Strain & f mol/mg Protein \\
\hline AKR & $35.9 \pm 5.3$ \\
BALB & $29.3 \pm 4.5$ \\
$\mathrm{BUB} / \mathrm{Ibg}$ & $40.1 \pm 4.1$ \\
$\mathrm{BUB} / \mathrm{J}$ & $46.1 \pm 7.7$ \\
$\mathrm{C} 3 \mathrm{H}$ & $39.5 \pm 2.9$ \\
$\mathrm{C} 57 / \mathrm{Bl}$ & $32.0 \pm 4.7$ \\
$\mathrm{DBA} / 1 \mathrm{~J}$ & $24.5 \pm 1.6$ \\
$\mathrm{DBA} / 2 \mathrm{Ibg}$ & $27.5 \pm 1.7$ \\
$\mathrm{ST} / \mathrm{b}$ & $45.9 \pm 2.1$ \\
\hline
\end{tabular}

Each value is the mean \pm standard error from three animals.

had been previously determined in these strains (Marks et al. 1989).

\section{Comparison between Auditory Evoked Response and $\left[{ }^{125} \mathrm{I}\right]-\alpha$-Bungarotoxin Binding and Hybridization of $\alpha-7$ mRNA in Situ}

$\left[{ }^{125} \mathrm{I}\right]-\alpha$-bungarotoxin labeling was examined histologically, together with in situ hybridization of mRNA for the $\alpha-7$ nicotinic receptor subunit, in sections of the hippocampus from the $\mathrm{ST} / \mathrm{b}, \mathrm{C} 3 \mathrm{H}, \mathrm{C} 57 / \mathrm{Bl}$, and $\mathrm{DBA} / 2 \mathrm{lbg}$ strains. The most intense $\alpha$-bungarotoxin labeling was in the dentate hilus and in stratum lacunosum moleculare, with moderately heavy labeling in the stratum oriens of CA3. In CA1, there was some labeling in the stratum oriens, extending to the alveus. The dentate granule cell layer and the pyramidal cell layers were mostly unlabeled. A similar pattern has been observed in the rat (Freedman et al. 1993). Across the four strains, the labeling was most intense in $\mathrm{ST} / \mathrm{b}$, intermediate in $\mathrm{C} 3 \mathrm{H}$ and $\mathrm{C} 57 / \mathrm{Bl}$, and least intense in DBA/2lbg (Figure 3). Computerized measurement of labeled areas, comparing $\mathrm{C} 3 \mathrm{H}, \mathrm{C} 57 / \mathrm{Bl}$, and $\mathrm{DBA} / 2 \mathrm{Ibg}$ sections to an ST/b section on the same slide, was used to quantify labeling in CA1, CA3, and the dentate hilus (Table 3). The binding of $\alpha$-bungarotoxin in the membrane binding assay correlated most closely with labeling in the CA3 region $(r=0.97, p<.01)$. Labeling in the CA3 region was also correlated with the conditioning amplitude $(r=$ $0.96, p<.01$ ).

In situ hybridization for the $\alpha-7$ nicotinic receptor subunit mRNA showed hybridization in the dentate gyrus granule cell layer and the pyramidal cell layer in all hippocampal subregions. This pattern was consistent with the labeling observed for $\alpha$-bungarotoxin. There was also hybridization in scattered cells throughout the hippocampus, including the dentate hilus, stratum lacunosum moleculare, and stratum oriens. As with $\alpha$-bungarotoxin labeling, there was a difference across the four strains. Particularly in the pyramidal regions, the ST/b showed the most intense hybridization,
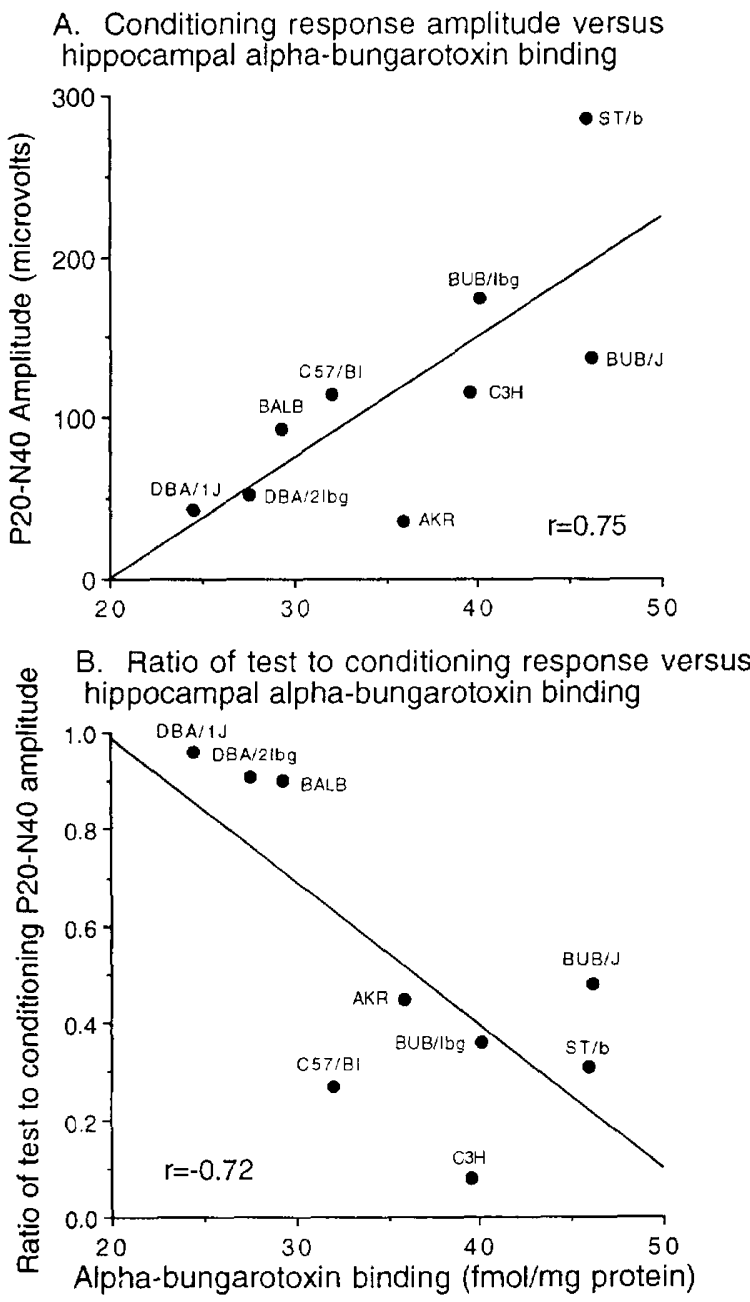

Figure 2. Relation between $\alpha$-bungarotoxin binding and the amplitude of the conditioning response (A) and the ratio of the test to the conditioning amplitude (B).

with the least hybridization in the DBA/2Ibg. Hybridization in the CA3 region was correlated with the ratio of the test amplitude to the conditioning amplitude ( $r=$ $-0.93, p<.05)$.

\section{DISCUSSION}

The purpose of this study was to assess the hippocampal response to paired auditory stimuli across strains of inbred mice that are known to differ in levels of hippocampal $\alpha$-bungarotoxin binding. Nine strains of mice that represented a continuum of hippocampal $\alpha$-bungarotoxin binding, as determined from published homogenate binding studies (Miner et al. 1986; Marks et al. 1989; Miner and Collins 1989) were assessed in an auditory conditioning/test paradigm. In all strains tested, a similar negative-going wave with a latency of approximately $40 \mathrm{msec}$ was elicited in the CA3 region of the 


\section{ALPHA-7}
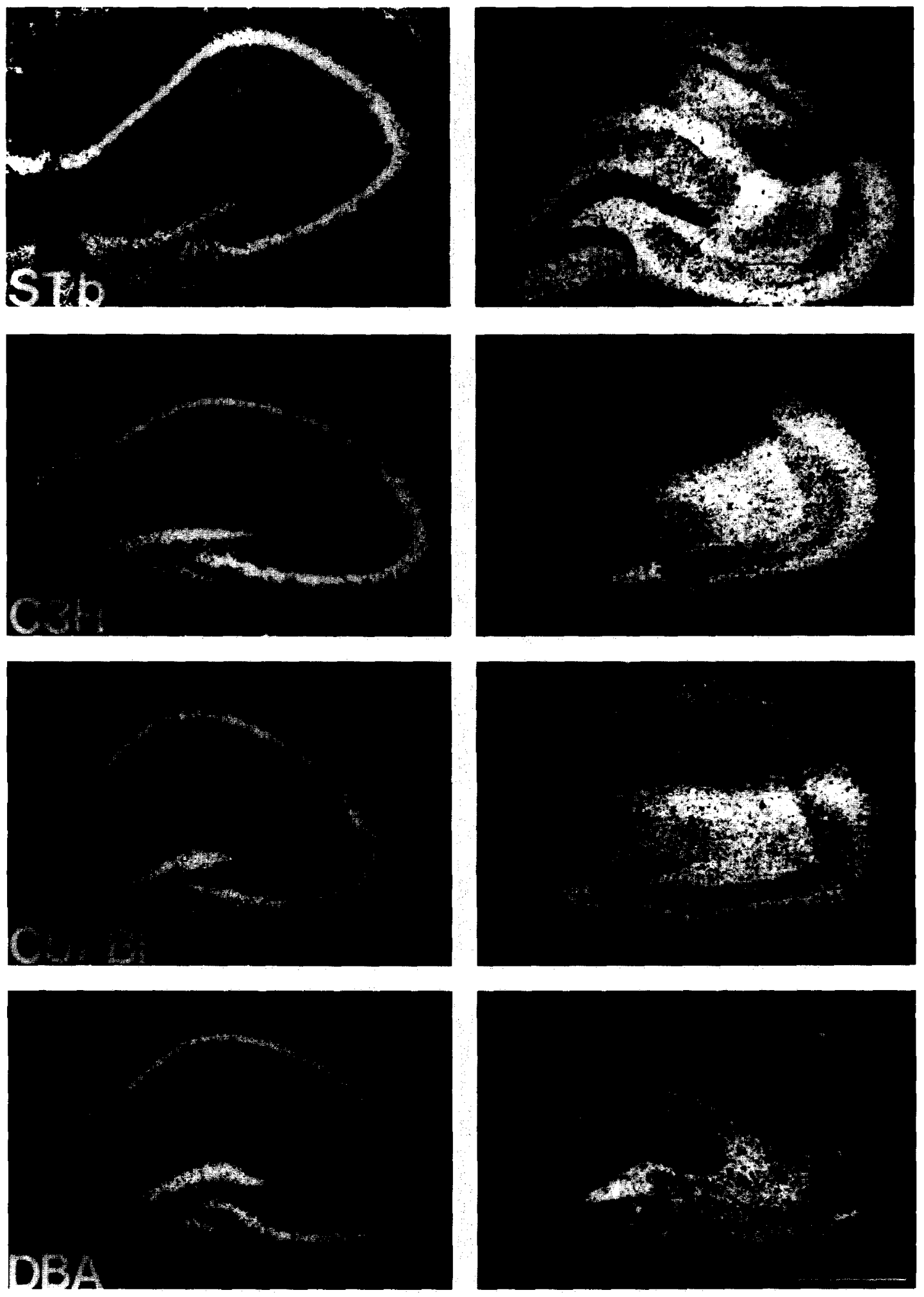

Figure 3. $\alpha$-Bungarotoxin binding (right) and in situ hybridization of mRNA for the $\alpha 7$ nicotinic receptor subunit (left) for four strains of mice. Hippocampal regions CA1, CA3, and the dentate granule cell layer (dg) are indicated. Calibration bar is $1 \mathrm{~mm}$. 
Table 3. $\left[{ }^{125} \mathrm{I}\right]-\alpha$-Bungarotoxin Binding and $\alpha 7$ mRNA in Situ Hybridization in Various Regions of the Hippocampus of Four Strains of Mice

\begin{tabular}{lcccc}
\hline Region & C3H & C57/BI & DBA/2Ibg & ST/b \\
\hline $\begin{array}{l}\alpha \text {-Bungarotoxin } \\
\text { CA1 }\end{array}$ & $0.45 \pm 0.08$ & $1.04 \pm 0.23$ & $0.81 \pm 0.39$ & $1.00^{\prime \prime}$ \\
CA3 & $0.72 \pm 0.07$ & $0.69 \pm 0.16$ & $0.43 \pm 0.04$ & $1.00^{\prime \prime}$ \\
Hilus & $0.66 \pm 0.06$ & $1.02 \pm 0.05$ & $0.86 \pm 0.11$ & $1.00^{\prime \prime}$ \\
$\alpha 7$ mRNA & & & & \\
CA1 & $0.93 \pm 0.05$ & $0.64 \pm 0.01$ & $0.57 \pm 0.05$ & $1.00^{\prime \prime}$ \\
CA3 & $1.07 \pm 0.10$ & $0.90 \pm 0.09$ & $0.76 \pm 0.18$ & $1.00^{\prime \prime}$ \\
Hilus & $0.77 \pm 0.07$ & $0.97 \pm 0.14$ & $0.88 \pm 0.04$ & $1.00^{\prime \prime}$ \\
\hline
\end{tabular}

Data are expressed as mean \pm SEM

"Levels of $\alpha$-bungarotoxin binding and mRNA for the $\mathrm{C} 3 \mathrm{H}, \mathrm{C} 57 / \mathrm{Bl}$, and DBA/2Ibg strains are expressed relative to the level in the ST/b strain which was set at 1 .

hippocampus in response to the stimuli. In outbred Sprague-Dawley rats, the $95 \%$ confidence limit for the ratio of test to conditioning amplitude was 0.4 or less (Miller et al. 1992). In three of the inbred strains, the ratios were all below 0.4 , similar to those of the outbred rats. In three strains, ratios as high as 0.6 were observed. The final three strains always produced responses to the test stimulus that were approximately the same amplitude as the conditioning stimulus (i.e., ratios of about 1). Hence, the nine strains of mice tested also represent a continuum with regard to their capacity to inhibit the hippocampal response in a repeated stimulus paradigm. This is the first study to identify strains of animals that reliably fail to inhibit the response to repeated auditory stimuli without pharmacological intervention. These animals thus represent a new potential model for assessing the neuropharmacology and neuroanatomical locus of sensory filtering.

A significant correlation was demonstrated between $\alpha$-bungarotoxin binding and both the amplitude of the conditioning response and the ratio of the test and conditioning amplitudes. These correlations do not prove that $\alpha$-bungarotoxin-sensitive nicotinic receptors are part of the mechanism of the regulation of sensory response. However, the results are consistent with previous pharmacological studies in rats, in which $\alpha$-bungarotoxin treatment decreased both the amplitude of the conditioning response and the suppression of the test response (Luntz-Leybman et al. 1992). In DBA/2lbg mice treated with nicotine and related nicotinic agonists, both parameters are increased (Stevens et al. 1995a, 1995b). A mechanism for the effects of altered expression of $\alpha$-bungarotoxin-sensitive cholinergic receptors on inhibitory gating of auditory responses is suggested by previous neurobiological studies with this paradigm. Auditory stimuli reach the hippocampus via a glutaminergic pathway from the entorhinal cortex and a cholinergic pathway from the medial septal nucleus. The entorhinal cortex does not habituate its re- sponse to repeated auditory stimuli (Stafekhina and Vinogradova 1975), whereas the medial septal nucleus does (Miller and Freedman 1993). During the conditioning response, the cholinergic neurons excite hippocampal pyramidal cells and interneurons, both of which have $\alpha$-bungarotoxin-sensitive receptors and express

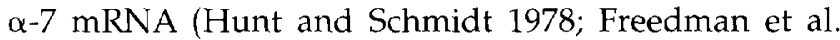
1993; Barrantes et al. 1995). The excitation causes prolonged interneuron activity (Miller and Freedman 1995), which releases sufficient GABA to activate inhibitory $\mathrm{GABA}_{B}$ receptors on presynaptic terminals near pyramidal cell apical dendrites (Isaacson et al. 1993). Then, although the entorhinal cortical neurons discharge in response to the test stimulus, their release of glutamate in the hippocampus is diminished. Evidence for this mechanism includes the finding that antagonism of $\mathrm{GABA}_{B}$ receptors or of $\alpha-7$ receptors are both sufficient to block the inhibition of the test stimulus (Luntz-Leybman et al. 1992; Hershman et al. 1995). $\alpha-7$ Receptors are rapidly and completely desensitized after agonist activation (Couturier et al. 1990), so that an adequate supply of receptors is needed to ensure that some of the population is available for activation as the pairs of stimuli are repeated. Some mouse strains may have failure of cholinergic activation of interneurons because a diminished number of receptors means that their entire population can become desensitized. One cause of diminished expression of $\alpha-7$ receptors is a variant in $\alpha-7$ mRNA splicing, observed in bovine adrenal chromaffin cells, that results in the assembly of an abnormal receptor (Garcia-Guzman et al. 1995). However, the genetic mechanisms responsible for variation in expression among the strains in this study are unknown.

An alternative explanation is that the diminished suppression of the test response is a result of a diminished conditioning response. For example, there could be a floor effect with small responses, so that the ratio would be high (i.e., close to unity) because both conditioning and test responses were approaching a similar minimum value as the conditioning amplitude decreased. However, the $\mathrm{C} 3 \mathrm{H}$ mice have larger conditioning waves that the DBA/2Ibg mice, but the DBA/2Ibg mice have larger test waves. Thus, the change in the ratio of the test to conditioning amplitude reflects changes in the test response as well as changes in the conditioning response. Another alternative explanation is that there is failure of activation of inhibitory mechanisms if the conditioning response is weak. If that hypothesis were true, then there would be a stronger correlation between the conditioning amplitude and the ratio of the test to the conditioning responses. Instead, the correlation between the two electrophysiological parameters is not significant. However, both parameters have significant correlation to $\alpha$-bungarotoxin binding, suggesting that the two electrophysiological parameters have an independent relationship to the nicotinic receptor. 
Although the inbred strains were chosen for study because of their differences in hippocampal $\alpha$-bungarotoxin binding, there are many other differences between the strains. In particular, DBA mice, the most deviant strain on both the sensory gating measures and $\alpha$-bungarotoxin binding, exhibit decreased catecholamine turnover (Kempf et al. 1974), increased numbers of forebrain cholinergic neurons (Albanese et al. 1985), increased acetylcholinesterase activity (Mandel et al. 1974), increased response to opiates (Frischknecht et al. 1988), and decreased protein kinase activity (Wehner et al. 1990). Given the current understanding of the neurobiology of the hippocampus, none of these differences are likely to account for the differences in auditory response observed in this study. Furthermore, as was found for high-affinity nicotine binding, none of these other measures are correlated across the different strains with parameters of auditory response. However, the correlation between gating of auditory response and $\alpha$-bungarotoxin binding has substantial variance, some of which might be caused by other neurotransmitter mechanisms known to affect inhibitory gating, such as norepinephrine (Adler et al. 1988; Bickford-Wimer et al. 1990). $\alpha$-Bungarotoxin-sensitive receptors are found in other brain areas in addition to the hippocampus. Values for other brain areas found in previous studies showed weaker correlations with auditory response than the hippocampal levels (Miner et al. 1986; Marks et al. 1989; Miner and Collins 1989). Indeed, the strongest correlations observed were for $\alpha$-bungarotoxin binding within the CA3 region itself, the source of the N40 wave. Nonetheless, the hypothesis that the critical nicotinic receptor is in the CA3 region requires further experimental verification.

One other hippocampal parameter may be closely related to auditory response. Several authors have reported diminished infrapyramidal mossy fiber innervation in the CA3 region in DBA mice, compared to $\mathrm{C} 3 \mathrm{H}$ and $\mathrm{C} 57 / \mathrm{Bl}$ strains (Barber et al. 1974; Fredens 1981; Schwegler and Lipp 1983; Lipp et al. 1989; Roullet and Lassalle 1992). ST /6Fi, a strain closely related to ST/b, has a larger innervation than the other three strains (Fredens 1981). There is a significant correlation $(r=$ $-0.96, p<.01$ ) between the ratio of the amplitude of the test and conditioning responses and the area of the mossy fiber innervation as measured on Timm's stained sections for these four strains (Roullet and Lassalle 1992). The alteration in hippocampal physiology could also reflect an alteration in mossy fiber innervation, rather than only an alteration in $\alpha$-bungarotoxin-sensitive receptors. However, $\alpha$-bungarotoxin-sensitive receptors have been purported to play a role in the early development of synaptic innervation in other brain areas (Fuchs 1989). Thus, it is possible that decreased nicotinic receptors result in both altered physiology and altered synaptic development.
The significance of $\alpha$-bungarotoxin-sensitive receptors for the neuropsychopharmacology of human disease remains uncertain. Heavy smoking, which could administer enough nicotine to activate this low-affinity receptor, is common in schizophrenics (de Leon et al. 1995). Diminished $\alpha$-bungarotoxin-binding has been found in portmortem examination of human hippocampus from schizophrenics, compared to a control group (Freedman et al. 1995). Schizophrenics have diminished suppression of the test response in an evoked potential paradigm similar to the one used in the present study, and this suppression is transiently normalized by cigarette smoking (Adler et al. 1993). Heritability of the diminished suppression in families with schizophrenic probands has been observed, with moderate evidence for linkage to the chromosomal site of the $\alpha-7$ receptor subunit (Coon et al. 1993; Freedman et al. 1994). Inbred mice with genetically determined deficiencies in $\alpha$-bungarotoxin-sensitive receptors and auditory sensory gating may thus model an important aspect of the pathophysiology of schizophrenia.

\section{ACKNOWLEDGMENTS}

This work was supported by NIMH grants MH44212, MH38321, and MH51931 and the Veterans Administration Medical Research Service.

\section{REFERENCES}

Adler LE, Pang K, Gerhardt G, Rose GM (1988): Modulation of the gating of auditory evoked potentials by norepinephrine: Pharmacological evidence obtained using a selective neurotoxin. Biol Psychiatry 24:179-190

Adler LE, Hoffer LD, Wiser A, Freedman R (1993): Normalization of auditory physiology by cigarette smoking in schizophrenic patients. Am J Psychiatry 150:1856-1861

Albanese A, Gozzo S, Iacopino C, Altavista MC (1985): Strain-dependent variations in the number of forebrain cholinergic neurons. Brain Res 334:380-384

Amaral DG, Kurz J (1985): An analysis of the origins of the cholinergic and noncholinergic septal projection to the hippocampal formation of the rat. J Comp Neurol 240:37-59

Andersen P, Eccles JC, Loyning Y (1964): Location of postsynaptic inhibitory synapses on hippocampal pyramids. J Neurophysiology 27:592-607

Barber RP, Vaughn JE, Wimer RE, Wimer CC (1974): Genetically associated variations in the distribution of dentate granule cell synapses upon the pyramidal cell dendrites in mouse hippocampus. J Comp Neurol 156:417-434

Barrantes GE, Rogers AT, Lindstrom J, Wonnacott S (1995): $\alpha$-Bungarotoxin binding sites in rat hippocampal and cortical cultures: Initial characterization, co-localization with $\alpha 7$ subunits and up-regulation by chronic nicotine treatment. Brain Res 672:228-236 
Bickford PC, Wear K (1994): Fimbria fornix lesions disrupt auditory sensory gating in the rat hippocampus. Soc Neurosci Abst 20:149.3

Bickford-Wimer PC, Nagamoto H, Johnson R, Adler LE, Rose GM, Freedman R (1990): Auditory gating in hippocampal neurons: A model system in the rat. Biol Psychiatry 27:189-192

Broadbent DE (1958): Perception and Communication. London, Pergamon

Clarke PB (1992): The fall and rise of neuronal alpha-bungarotoxin binding proteins. Trends Pharmacol Sci 13:407413

Cook JD, Ellinwood EH, Wilson WP (1968): Auditory habituation at primary cortex as a function of stimulus rate. Exp Neurobiol 21:167-175

Coon H, Plaetke R, Holik J, Hoff M, Myles-Worsley M, Freedman R, et al. (1993): Use of a neurophysiological trait in linkage analysis of schizophrenia. Biol Psychiatry 34:277-289

Couturier S, Bertrand D, Matter JM, Hernandez MC, Bertrand S, Miller N, Valera S, Barkas T, Ballivet M (1990): A neuronal nicotinic acetylcholine receptor subunit (alpha 7) is developmentally regulated and forms a homo-oligomeric channel blocked by alpha-bungarotoxin. Neuron 5:847-856

De Leon J, Mahmood D, Canuso C, White AO, Stanilla JK, Simpson GM (1995): Schizophrenia and smoking: An epidemiological survey in a state hospital. Am J Psychiatry 152:453-455

Foster TC, Hampson RE, West MO, Deadwyler SA (1988): Control of sensory activation of granule cells in the fascia dentate by extrinsic afferents: Septal and entorhinal inputs. J Neurosci 8:3869-3878

Fredens K (1981): Genetic variation in the histoarchitecture of the hippocampal region of mice. Anat Embryol 161:265-281

Freedman R, Wetmore C, Strömberg I, Leonard S, Olson L (1993): $\alpha$-Bungarotoxin binding to hippocampal interneurons: Immunocytochemical characterization and effects on growth factor expression. J Neurosci 13:19651975

Freedman R, Adler LE, Bickford P, Byerley W, Coon H, Cullum CM, Griffith JM, Harris JG, Leonard S, Miller C, Myles-Worsley M, Nagamoto HT, Rose G, Waldo M (1994): Schizophrenia and nicotinic receptors. Harvard Rev Psychiatry 2:179-192

Freedman R, Hall M, Adler LE, Leonard S (1995): Evidence in postmortem brain tissue for decreased numbers of hippocampal nicotinic receptors in schizophrenia. Biol Psychiatry 38:22-33

Frischknecht HR, Siegfried B, Waser PG (1988): Opioids and behavior, genetic aspects. Experientia 44:473-481

Fuchs JL (1989): [125I]-Alpha-bungarotoxin binding marks primary sensory area in developing rat neocortex. Brain Res 501:223-234

Garcia-Guzman M, Sala F, Sala S, Campos-Caro A, Stühmer W, Gutiérrez LM, Criado M (1995): $\alpha$-Bungarotoxin-sensitive nicotinic receptors on bovine chromaffin cells: Molecular cloning, functional expression and alternative splicing of the $\alpha 7$ subunit. Eur J Neurosci 7:647-655
Hershman KM, Freedman R, Bickford PC (1995): GABAB antagonists diminish the inhibitory gating of auditory response in the rat hippocampus. Neurosci Lett 190:133136

Hunt SP, Schmidt J (1978): The electron microscopic autoradiographic localization of $\alpha$-bungarotoxin binding sites within the central nervous system of the rat. Brain Res 142:152-159

Isaacson JS, Solis JM, Nicoll RA (1993): Local and diffuse synaptic actions of GABA in the hippocampus. Neuron 10:165-175

Johnson DS, Stroessner-Johnson HM, Boulter J, Amaral DG, Heinemann S (1991): Distribution of alpha-7 neuronal nicotinic mRNA in the rat CNS. Soc Neurosci Abs 17:249

Kempf E, Greilsamer J, Mack G, Mandel P (1974): Correlation of behavioral differences in three strains of mice with differences in brain amines. Nature 247:483-485

Lipp HP, Schwegler H, Crusio WE, Wolfer DP, LeisingerTrigona MC, Heimrich B, Driscoll P (1989): Using genetically-defined rodent strains for the identification of hippocampal traits relevant for two-way avoidance behavior: A non-invasive approach. Experientia 45:845-857

Logel J, Dill D, Leonard S (1992): Synthesis of cRNA probes from PCR-generated DNA. BioTechniques 4:604-610

Lowry OH, Rosebrough NJ, Farr AL, Randall RJ (1951): Protein measurement with the Folin phenol reagent. J Biol Chem 193:265-275

Luntz-Leybman V, Bickford PC, Freedman R (1992): Cholinergic gating of response to auditory stimuli in rat hippocampus. Brain Res 587:130-136

Mandel P, Ayad G, Hermetet JC, Ebel A (1974): Correlation between choline acetyltransferase activity and learning ability in different mouse strains and their offspring. Brain Res 72:65-70

Marks MJ, Romm E, Campbell SM, Collins AC (1989): Variation of nicotinic binding sites among inbred strains. Pharmacol Biochem Behav 33:679-689

Marks MJ, Pauly JR, Gross SD, Deneris ES, Hermans-Borgmeyer I, Heinemann SF, Collins AC (1992): Nicotine binding and nicotinic receptor subunit RNA after chronic nicotine treatment. J Neurosci 12:2765-2784

Miller CL, Freedman R (1993): Medial septal neuron activity in relation to an auditory sensory gating paradigm. Neurosci 55:373-380

Miller CL, Freedman R (in prep): The activity of hippocampal interneurons and pyramidal cells during the response of the hippocampus to repeated auditory stimuli. Neurosci

Miller CL, Bickford PC, Luntz-Leybman V, Adler LE, Gerhardt GA, Freedman R (1992): Phencyclidine and auditory sensory gating in the hippocampus of the rat. Neuropharmacol 31:1041-1048

Miner LL, Collins AC (1989): Strain comparison of nicotineinduced seizure sensitivity and nicotine receptors. Pharmacol, Biochem Behav 33:469-475

Miner LL, Marks MJ, Collins AC (1986): Genetic analysis of nicotine-induced seizures and hippocampal nicotinic receptors in the mouse. J Pharmacol Exp Ther 239:853860

Rollins YD, Hall M, Heman KL, Dobelis P, Walrond JP, Rose 
GM, Leonard S (1994): Effect of methyllycaconitine and related alkaloids, in vitro and in vivo, at the $\alpha$-bungarotoxin binding site in rodent brain. Soc Neurosci Abs 20:1133

Roullet P, Lassalle JM (1992): Behavioral strategies, sensorial processes and hippocampal mossy fibre distribution in radial maze performance in mice. Behav Brain Res $48: 77-85$

Schoepfer R, Conroy WG, Whiting P, Gore M, Lindstrom J (1990): Brain $\alpha$-bungarotoxin binding protein cDNAs and MAbs reveal subtypes of this branch of the ligandgated ion channel gene superfamily. Neuron 5:35-48

Schwegler H, Lipp HP (1983): Hereditary correlations between neuronal circuitry and behavior: Correlations between the proportions of hippocampal synaptic fields in the regio inferior and two-way avoidance in mice and rats. Behav Brain Res 7:1-38

Senba K, Iwahara S (1974): Effects of medial septal lesions on the hippocampal electrical activity and the orienting response to auditory stimulation in drinking rats. Brain Res 66:309-320

Simmons DM, Arriza JL, Swanson SW (1989): A complete protocol for in situ hybridization of messenger RNAs in brain and other tissues with radiolabeled singlestranded RNA probes. J Histotechnol 12:169-181

Slotnick BM, Leonard CM (1975): A Stereotaxic Atlas of the Albino Mouse Forebrain (HEW Publication No. 75-100). Rockville, MD, Department of Health Education and Welfare
Stafekhina VS, Vinogradova OS (1975): Sensory characteristics of the cortical input to the hippocampus: The entorhinal cortex. Zh Vyssh Nerv Deiat Im I P Pavlova 25:119-127

Stevens KE, Kem WR, Strom J, Freedman R (1995a): DMXB, an agonist selective for the $\alpha$-bungarotoxin binding site, transiently normalizes auditory gating in the DBA/2 mouse. Soc Neurosci Abs 21:1334

Stevens KE, Wear KD, Freedman R (1995b): Effects of nicotinic agonists in animal models of hippocampal sensory gating deficits. Pharmacol Biochem Behav (submitted)

Swanson LW (1983): The hippocampus and the concept of the limbic system. In Seifert, W. (ed), Neurobiology of the Hippocampus. London, Academic Press, pp 3-19

Vinogradova OS (1975): Functional organization of the limbic system in the process of registration information: Facts and hypotheses. In Isaacson, RL, Pribram KH (eds), The Hippocampus. New York, Plenum Press, vol 2. pp 3-69

Wehner JM, Sleight S, Upchurch M (1990): Hippocampal protein kinase c activity is reduced in poor spatial learners. Brain Res 523:181-187.

Yanovsky Y, Brankack J, Hass HL (1995): Differences of CA3 bursting in $\mathrm{DBA} / 1$ and $\mathrm{DBA} / 2$ inbred mouse strains with divergent shuttle box performance. Neuroscience 64 2:319-325 